\title{
2009 MRS FALL MEETING LODGING AND TRAVEL
}

The 2009 MRS Fall Meeting in Boston will be held at the Hynes Convention Center and Sheraton Boston Hotel. For your convenience, special room rates have been arranged at the hotels listed below. Rooms are limited at these rates, so make your reservations early. Reservations can be made online at www.mrs.org. Your patronage of the official hotels enables MRS to secure the meeting space at a greatly reduced rate.

\section{LODGING}

\section{Sheraton Boston Hotel}

39 Dalton Street, Boston, MA 02199; 617-236-2000; Fax 617-236-1702

Room Rate: \$176 Single*; \$188 Double*

(+\$20 each for additional persons in guest room)

Deadline November 9

Boston Marriott Copley Place

110 Huntington Avenue, Boston, MA 02116; 617-236-5800; Fax 617-236-5885

Room Rate: \$171 Single; \$187 Double; \$197 Triple; \$207 Quad

Deadline November 9

The Westin Copley Place

10 Huntington Avenue, Boston, MA 02116; 617-262-9600; Fax 617-424-7502 Room Rate: \$173 Single*; \$193 Double*

(+\$25 each for additional persons in guest room)

Deadline November 9

\section{Hilton Boston Back Bay}

40 Dalton Street, Boston, MA 02115; 617-867-6000; Fax 617-867-6104

Room Rate: \$166 Single or Double; \$176 Triple or Quad

Deadline November 6

The Boston Park Plaza Hotel \& Towers

50 Park Plaza, Boston, MA 02116; 617-426-2000; Fax 617-423-1708

Room Rate: \$160 Single*; \$160 Double*

(+\$20 each for additional persons in guest room)

Deadline November 20

Embassy Suites Boston at Logan Airport

207 Porter Street, Boston, MA 02128; 617-567-5000; Fax 617-567-5999

Room Rate: \$129 Single*; \$139 Double*; \$149 Triple*; \$159 Quad*

Deadline October 21

\section{TRANSPORTATION/PARKING/CHILDCARE}

\section{Transportation}

Check the MRS Web site at www.mrs.org for information on airport subway service to MRS hotels.

Taxicabs are available around the clock. The average fare to the Back Bay area hotels is approximately $\$ 40-50$.

For more information on other ground transportation to and from Logan International Airport, call MASSPORT, 24 hours a day, at 1-800-23-LOGAN.

\section{Parking}

Parking in the Back Bay area costs approximately $\$ 60$ per day. Parking is available in the garage between the Boston Marriott and the Westin Hotels at Copley Place. There is also parking at the Prudential Center Complex.

\section{Childcare}

The Materials Research Society is pleased to announce that a limited number of childcare grants will be awarded to registered 2009 MRS Fall Meeting attendees who are bringing young children or who incur extra expenses in leaving them at home (i.e., added hours of daycare or babysitting services). For more information, go to www.mrs.org/f09_childcare.

There will be no MRS-sponsored childcare services on site at the 2009 MRS Fall Meeting. MRS does not sanction or recommend childcare providers, and does not assume responsibility or liability for child care services of any sort. It is the responsibility of the parents to thoroughly investigate all childcare providers.

\section{MRS FALL SYMPOSIUM TUTORIALS • HYNES CONVENTION CENTER}

TUTORIAL ATTENDANCE IS OPEN TO ALL MEETING ATTENDEES AT NO EXTRA CHARGE. DETAILS AVAILABLE ON THE MRS WEB SITE.

\section{SUNDAY}

\section{SYMPOSIUIM F}

Fundamentals of Multiferroic and Ferroelectric Materials

Sunday, November 29, 8:30 am-3:00 pm, Room 200

\section{SYMPOSIUIM G}

Magnetic Shape Memory Alloys-From Fundamentals Toward Applications

Sunday, November 29, 1:30-5:00 pm, Room 201

\section{SYMPOSIUM}

III-Nitride-based Sensors for Gas, Chemical, and Medical Applications Sunday, November 29, 1:30-5:00 pm, Room 207

\section{SYMPOSIUM L}

Properties and Applications of Carbon Nanotubes and Graphene Sunday, November 29, 8:30 am-5:00 pm, Room 208

\section{SYMPOSIUM 0}

Optics of Nanostructures

Sunday, November 29, 1:30-5:00 pm, Room 202

\section{SYMPOSIUIM S}

Fundamentals of Organic Optoelectronic Materials and Devices Sunday, November 29, 1:30-5:00 pm, Room 210

\section{SYMPOSIUMT T}

Analysis of Nanomaterials for Polymer Electrolyte Membrane Fuel Cells

Sunday, November 29, 1:30-5:00 pm, Room 203

\section{SUNDAY}

SYMPOSIUM Z

Micro-energy Harvesting-Current Status of Technology, Field of Applications, and Outlook

Sunday, November 29, 1:30-5:00 pm, Room 206

\section{SYMPOSIUM GG}

Experimental and Simulation Methods for the Study of Plasticity in Small Volumes

Sunday, November 29, 8:30 am-5:00 pm, Room 310

\section{SYMPOSIUM 00}

AFM with Atomic Resolution-From Basic Concepts to Applications in UHV and Liquids

Sunday, November 29, 1:30-5:00 pm, Room 209

\section{SYMPOSIUM XX}

Interfacing Inorganic Nanoparticles with Biology-Synthesis, Coupling Chemistry, Sensor Design, and Imaging Sunday, November 29; 1:00-5:00 pm, Room 309

\section{SYMPOSIUM YY}

Compatibility of Nanomaterials-The Role of Their Size and Surfaces Sunday, November 29, 1:30-4:30 pm, Room 313

MONDAY

SYMPOSIUM EE

Introduction and Recent Developments of Metamaterials

Monday, November 30, 1:30-5:00 pm, Room 104 